\title{
EVIDENCE FROM FLANK RIDGES FOR LONG-TERM DIMINISHING MOVEMENTS OF THE SLUMGULLION LANDSLIDE, HINSDALE COUNTY, COLORADO
}

\section{By Mario Parise 1 \\ Andrea Moscariello ${ }^{2}$ \\ Robert W. Fleming ${ }^{3}$}

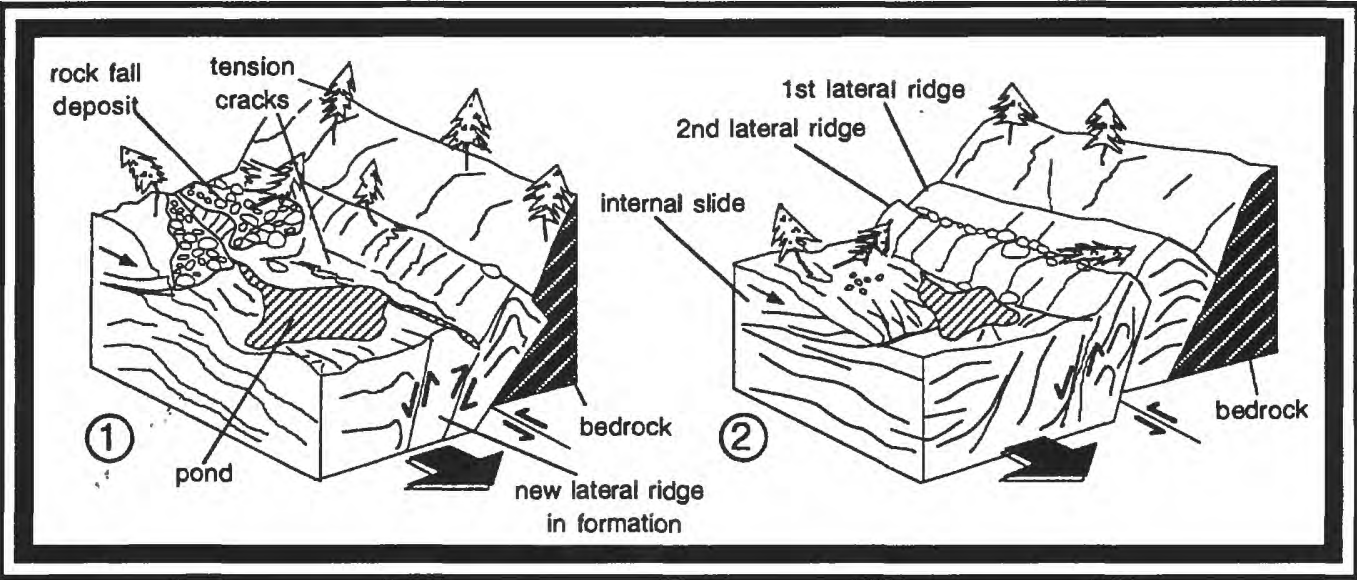

\section{Open-File Report 97-517}

This report is preliminary and has not been reviewed for conformity with U.S. Geological Survey editorial standards and nomenclature. Any use of trade, product, or firm names is for descriptive purposes only and does not imply endorsement by the U.S. Government.

1National Research Council of Italy CERIST, via Orabona 4, 70125

Bari, Italy
2Institut F.A. Forel

Universite de Geneve

10 , route de Suisse, $\mathrm{CH}-1290$

Versoix, Switzerland
3U.S. Geological Survey

Denver, CO 


\section{CONTENTS}

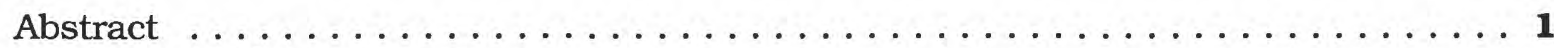

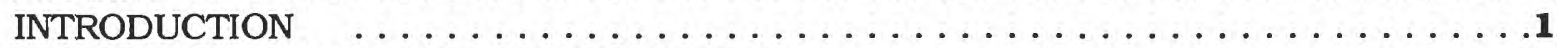

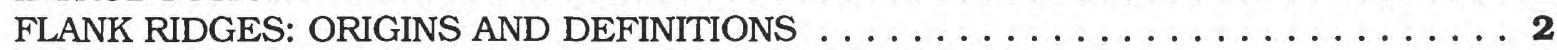

THE FLANK RIDGES AT THE SLUMGULLION LANDSLIDE $\ldots \ldots \ldots \ldots \ldots \ldots \ldots$

Flank ridges near the narrowest part of the landslide $\ldots \ldots \ldots \ldots \ldots \ldots$

Flank ridges downslope from the active toe $\ldots \ldots \ldots \ldots \ldots \ldots \ldots \ldots$

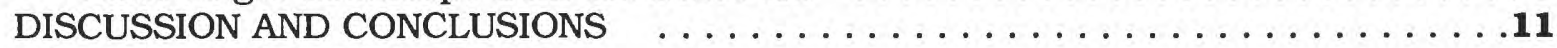

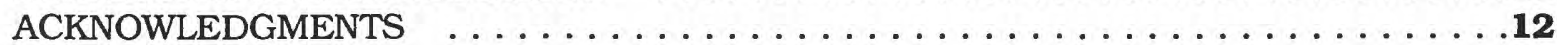

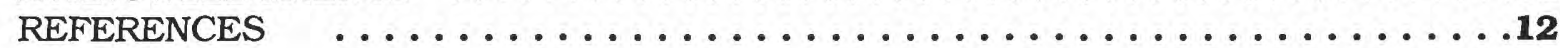

\section{FIGURES}

1. Location map showing the boundaries of both inactive and active parts of the

Slumgullion earth flow . . . . . . . . . . . . . . . . .

2. Sketch showing formation of flank ridges in earth flows $\ldots \ldots \ldots \ldots \ldots \ldots$

3. Sketch of the sector near the secondary source area on the right side of the earth flow, showing the several generations of inactive lateral ridges and their

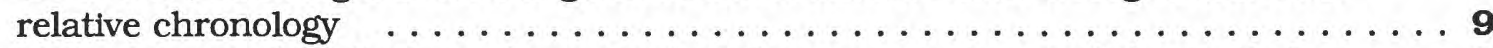

4. Transverse profiles (looking downslope) at the narrowest part of the earth flow . . . .9

5. Simplified geomorphological sketch of the middle-lower portion of the Slumgullion earth flow, from the active to the inactive toe . . . . . . . . 10

6. Transverse profiles (looking downslope) at the middle-lower part of the old Slumgullion earth flow. Location of profiles are shown in fig. $5 \ldots \ldots \ldots \ldots \ldots$

7. Block diagram showing a possible model explaining the concentration of large boulders at the top of flank ridges at the Slumgullion earth flow . . . . . . . 11

\section{TABLES}

1. Morphometry of the inactive Slumgullion earth flow. . . . . . . . . . 3

2. Features used for the chronology of formation of the flank ridges at the

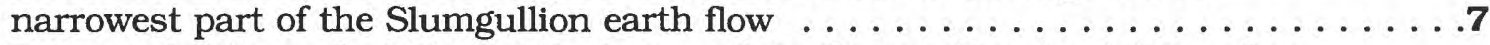

3. Estimated values of width and thickness of the Slumgullion landslide, after the formation of main sets of flank ridges recognized on the landslide. $\ldots \ldots \ldots 7$ 


\title{
EVIDENCE FROM FLANK RIDGES FOR LONG-TERM DIMINISH- ING MOVEMENTS OF THE SLUMGULLION LANDSLIDE, HINSDALE COUNTY, COLORADO
}

\author{
By Mario Parise, Andrea Moscariello, and Robert W. Fleming
}

\begin{abstract}
The Slumgullion landslide, in southwestern Colorado, is a complex phenomenon consisting of an active landslide currently moving on the upper-middle part of an older, larger, and inactive landslide. It is bounded for most of its length by flank ridges that are linear ridges of landslide material that have formed during movement along the lateral boundaries of the landslide. Flank ridges formed by deformation of landslide material, as well as formed by deposition of landslide material onto the adjacent ground surface, were recognized on the inactive Slumgullion landslide.

Flank ridges are the best preserved features in the deposits of the inactive Slumgullion landslide. They extend continuously for several hundred meters, following the landslide boundaries. The several generations of flank ridges were mapped on aerial photographs and later field checked; observation of their main geomorphic, pedologic, and sedimentologic characters helped in reconstructing the chronology of their formation. An attempt was also made to correlate the identified sets of flank ridges with the known history of movement of the Slumgullion landslide.

Maps and profiles were used to estimate previous width and thickness of the landslide at the time of formation of the identified sets of flank ridges. Comparison of these values with the present width and thickness of the Slumgullion landslide showed a thinning and narrowing trend, which will eventually result in inactivity of the presently active
\end{abstract}

part of the landslide, unless a new amount of material is available from the source area.

\section{INTRODUCTION}

Previous studies of the active part of the Slumgullion landslide have ${ }^{(1)}$ documented the growth of flank ridges and noted the presence of relict flank ridges in both the active and inactive deposits of the slide. This report documents the relative ages and distribution of relict flank ridges in the inactive landslide deposits. The relict ridges indicate past boundaries and height of the surface of the slide. The distribution of the ridges provides evidence for gradual thinning and narrowing of the slide.

The first section on flank ridges reviews the literature and discusses terminology. Next, descriptions are presented for two areas on the inactive Slumgullion landslide. The first area is at the narrowest part of the landslide, and the second is downslope from the active toe.

The description of the flank ridges and their distribution on the landslide were used to identify sets of ridges that formed at the same time. The elevation of the surface and the width of the Slumgullion landslide at these times of formation of each set of flank ridges provide a historical perspective on long-term changes in landslide movement.

The boundaries of both active and inactive parts of the Slumgullion earth flow are shown in figure 1. Main dimensions of the entire earth flow complex are listed in table 1.

\footnotetext{
(1) Observations dealing with kinematics of the movement at Slumgullion site showed that most of the movement of the active part of the Slumgullion earth flow takes place along the shear surfaces which bound the landslide on its sides (Crandell and Varnes, 1961; Guzzi and Parise, 1992; Baum and Fleming, 1996; Savage and Fleming, 1996; Fleming and others, 1996; Fleming and others, in press); therefore, it is more correct to refer to it as an earth slide or landslide. However, since it has been described for a long time as earth flow (and sometimes also used as typical example for this category of slope movement), the term earth flow has become and still remains traditionally popular for the Slumgullion. In this paper, we use interchangeably both the terms earth flow and landslide in referring to the slope movement.
} 


\section{FLANK RIDGES: ORIGINS AND DEFINITIONS}

Flank ridges are among the most widely recognized and described surface features in slope movements and are particularly common in flow-type movements. The ridges are long, linear convex-up mounds of material of highly variable dimensions. In general, they are steep sided, with slopes in excess of $30^{\circ}$ and appear to have a scale relationship to the feature in which they form. Ridges have been seen on the flanks of small mudflow deposits that are only a few centimeters high and wide.
On large slow-moving landslides, they are typically in the range of 2 to $15 \mathrm{~m}$ high. Named levees, lateral ridges or flank ridges, these features have been a topic of study in slope movements worldwide. Ridges have been described in specific deposits for many years (e.g. Rickmers, 1913; Blackwelder, 1928; Sharp, 1942; Johnson, 1970). Origin and growth of flank ridges in earth flows have been described in detail by Keefer and Johnson (1983), Fleming and Johnson (1989), and Baum and others (1993). Although they have presented some data that constrain how they form, coherent explanations of their processes of formation are still lacking.

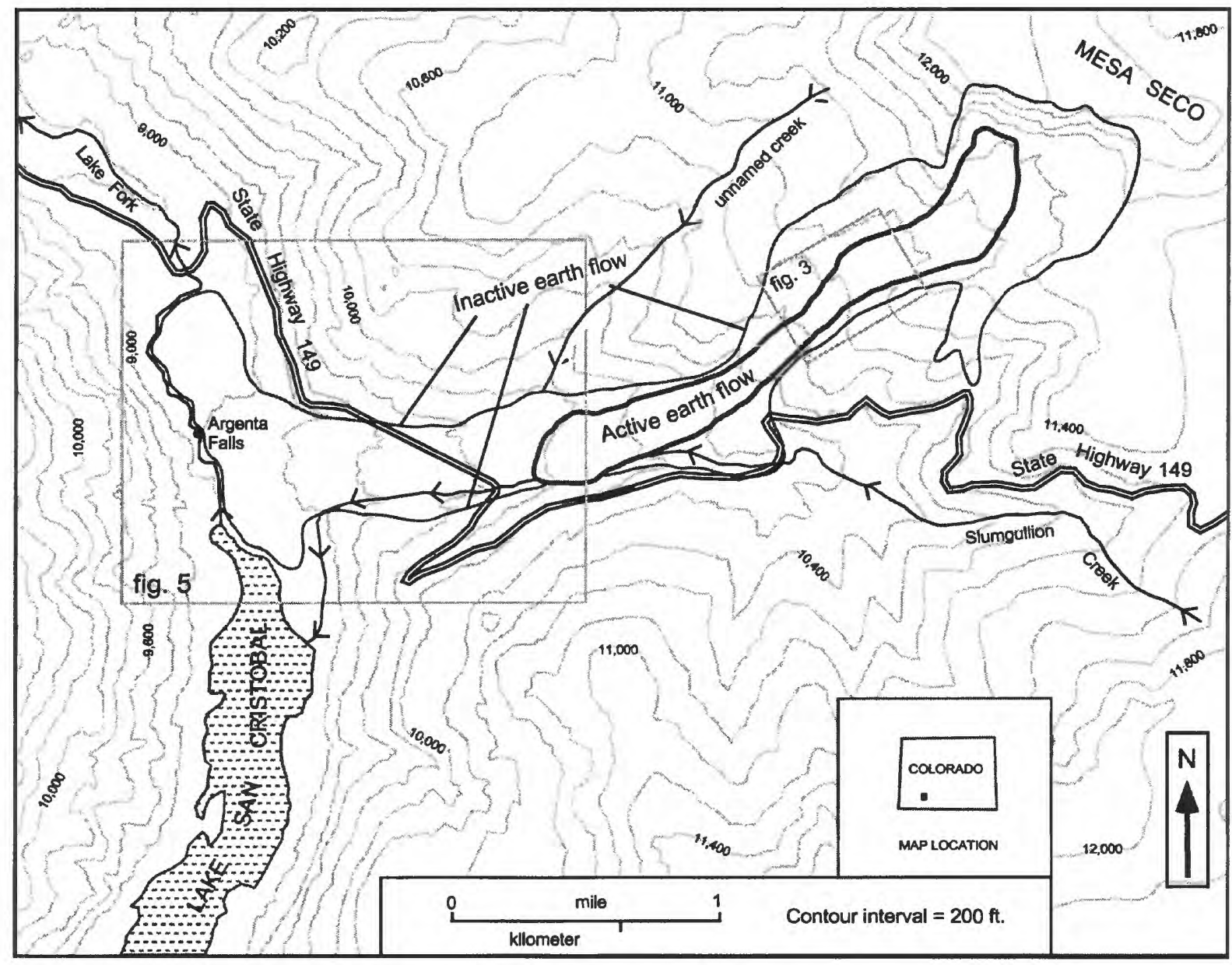

FIGURE 1.-- Location map showing the boundaries of both inactive and active parts of the Slumgullion earth flow. The active part of the landslide complex is contained within the boundaries of the inactive landslide everywhere except for a small stretch on the south side near the toe. 
TABLE 1.-- Morphometry of the inactive Slumgullion earth flow (after Parise and Guzzi, 1992)

\begin{tabular}{|c|c|}
\hline Feature & dimension \\
\hline Area of deposit (2) & $4.74 \mathrm{~km}^{2}$ \\
\hline Length & $6.8 \mathrm{~km}$ \\
\hline $\begin{array}{l}\text { Width } \\
\text { - head } \\
\text { - narrowest part } \\
\text { - toe }\end{array}$ & $\begin{array}{l}1,130 \mathrm{~m} \\
290 \mathrm{~m} \\
530 \mathrm{~m}\end{array}$ \\
\hline $\begin{array}{l}\text { Relief } \\
\quad \text { - elevation of top } \\
\text { - elevation of tip }\end{array}$ & $\begin{array}{l}3,700 \mathrm{~m} \\
2,700 \mathrm{~m}\end{array}$ \\
\hline $\begin{array}{l}\text { Average slope } \\
\text { - deposit only } \\
\text { - including main scarp }\end{array}$ & $\begin{array}{l}7(12 \%) \\
8(14 \%)\end{array}$ \\
\hline $\begin{array}{l}\text { Thickness } \\
\text { - average } \\
\text { - average on thalweg of buried valley } \\
\text { - maximum }\end{array}$ & $\begin{array}{l}40 \mathrm{~m} \\
90-100 \mathrm{~m} \\
140 \mathrm{~m} \\
\end{array}$ \\
\hline $\begin{array}{l}\text { Volume } \\
\text { - earth flow deposit } \\
\text { - detached mass }{ }^{(3)}\end{array}$ & $\begin{array}{l}168 \times 10^{6} \mathrm{~m}^{3} \\
142 \times 10^{6} \mathrm{~m}^{3}\end{array}$ \\
\hline Length : width & $>6: 1$ \\
\hline
\end{tabular}

(2)Including the deposit identified by Chleborad (1993).

(3)Including a 30\% bulking factor; for further details see Parise and Guzzl (1992).

Keefer and Johnson (1983) and Fleming and Johnson (1989) distinguished ridges formed by deformation of landslide debris from those formed by deposition (fig. 2). The deformational ridges form as a result of a screw-like motion of material moving up and out of the landslide surface. The external boundary of the ridge is typically slickensided and may contain an intruded dike of clay along the margin. Fleming and Johnson (1989) surveyed the growth of flank ridges and development of associated structures on landslides in Utah. The crests of ridges rise relative to adjacent material that is moving downhill as a result of displacement. For the landslides in Utah, the relative growth of a ridge was about $5 \mathrm{~cm}$ per $\mathrm{m}$ of landslide translation. Strain measurement revealed tension at the crest of the ridge and compression on the flank of the ridge (Fleming and Johnson, 1989). The depositional ridges form by overflow of landslide material onto the adjacent ground surface, and by remobilization of landslide material that leaves in place a ridge as a type of lag deposit. Depositional ridges are formed outside the strike-slip fault on the flanks of the landslide.
Corominas (1995) has reviewed many of the proposed mechanisms for formation of flank ridges. Ridges have been described on flows of ice, mud, debris, and lava as well as on true landslides. In part, the wide variety of proposed mechanisms for formation of flank ridges results from the many different situations and materials in which they have been observed to occur. Corominas (1995) made a strong case for basal erosion and shear in the development of flank ridges. There are situations, such as along the flanks of lava flows, however, where basal erosion cannot have played a role even though the ridges are morphometrically similar to those on the surface of a moving landslide. Thus, in this paper, we do not attempt to document processes of formation but rather we use the ridges as morphological indicators of previous boundaries of landslides.

The great majority of the flank ridges at the Slumgullion landslide appears to have formed along the boundary between active and inactive landslide movement as a result of shear displacement on the bounding strike-slip fault. The bounding strike-slip fault occurs on the outside edge of the ridge, and the crest of the ridge is higher than adjacent 


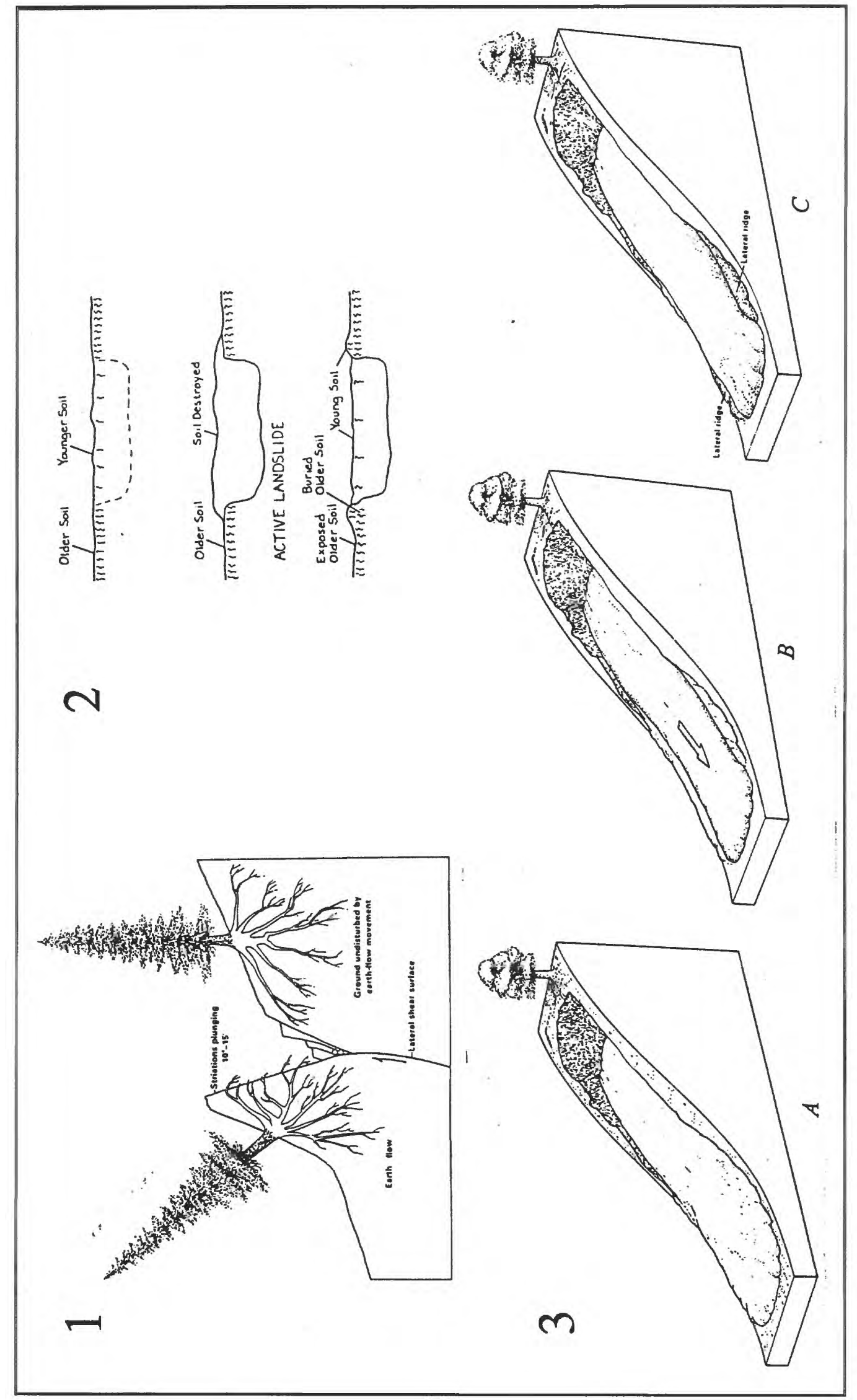

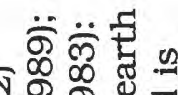
궁 \% 동혈 들

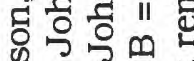

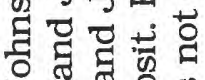
200 \%

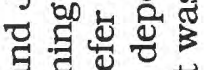
त ह

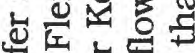
出苛节 幽 중 \& 造 च 댕ㅁㅇ

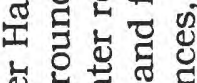
进品要

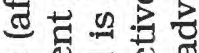
品要 늠

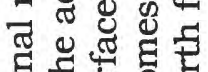
of 능

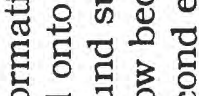

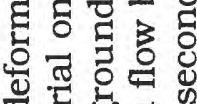
읭

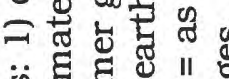
is 훙 훙 o

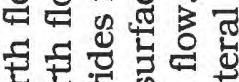
敋 5 听 \% 政

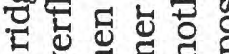

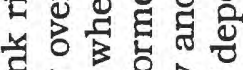
궁응

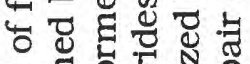
质 过 政

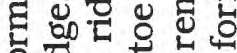

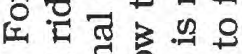
ง 和额

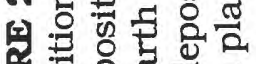

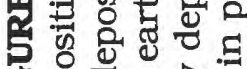

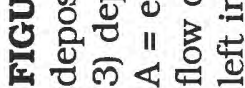


landslide material. A few ridges were noted to form within the active landslide, and they invariably appeared to form adjacent to longitudinal strike-slip faults within the body of the landslide. In plan view, the flank ridges are elongate, curved convex and point downward at their termini. Their width is always small with respect to their length. Height of the ridges ranges from tens of centimeters to $30 \mathrm{~m}$. Flank ridges are currently as much as 15-20 $\mathrm{m}$ higher than adjacent landslide material. In cross-section, flank ridges show a convex-upward curve and V-shaped troughs on both sides that is emphasized by active erosion. The inner side is generally steeper than the outer. Where height and width are comparable, the ridge is rounded; with increasing height, narrow ridges with steep slopes on both sides form. Maximum observed steepness on the sides of the ridges is between $35^{\circ}$ and $40^{\circ}$.

The crest of the ridge is generally a distinct line, parallel to the earth-flow boundary. If the ridge is wider than typical, it may contain a double crest at its top, with the two crests separated by a slight intervening valley, or a small furrow. In most cases the double crest derives from erosion along the top surface of the ridge; however, in places, the furrow may represent overlapping of successive ridges.

Ridges were recognized to be forming within $200 \mathrm{~m}$ of the head and about $500 \mathrm{~m}$ of the toe of the active Slumgullion landslide. The toe of the active landslide is advancing over the surface of the old, inactive landslide and is spreading as it moves downslope. Thus, there is little opportunity for flank ridges to form there. In the inactive landslide, flank ridges are present from near the head to the toe of movement. In places there are up to four subparallel ridges present in the inactive landslide debris just outside the flanks of the active landslide.

Flank ridges that have formed along the flanks of a landslide provide a basis to evaluate the history of movement in much the same way as moraines are useful indicators of movement history of a glacier. As long as earlier glacial episodes were more extensive than later episodes, the moraines can provide documentation of glacial advances and retreats. A flank ridge that is within the boundaries of an active landslide is soon destroyed by the differential deformations that occur within moving ground. However, ridges left outside the boundaries of active movement are among the best-preserved features of past landsliding. And, similar to the record of valley glaciers, there typically forms a pair of flank ridges on opposite sides of the landslide that provide a duel record of a previous position of active landslide movement. If a landslide enlarges laterally and incorporates deposits from an earlier stage of movement, the ridge on the side of the enlargement will typically be destroyed, but an unpaired ridge may remain.

\section{THE FLANK RIDGES AT THE SLUMGULLION LANDSLIDE}

Flank ridges were noted and described by some of the first observers of the Slumgullion landslide. Cross (1909) reported that the flow is bounded for nearly its entire length by two moraine-like lateral ridges of very sharp outline (Cross, 1909, p. 126). Some of the ridges bounding the earth flow are visible on photographs taken by Cross, and reported by Howe in his study of landslides in the San Juan Mountains of Colorado (Howe, 1909).

The inactive Slumgullion earth flow is bounded on its sides by flank ridges for most of its length in the valley of Slumgullion Creek. At the terminal part of the earth flow, in the valley of the Lake Fork of the Gunnison River, only a few remnants of flank ridges are recognizable (the most distal are two parallel ridges, located on the right flank of the earth flow, about $600 \mathrm{~m}$ uphill from the inactive toe; $c f$. fig. 5).

At the upper and middle part of the old earth flow, flank ridges extend continuously for several hundred $\mathrm{m}$, and are generally parallel to the landslide boundaries. Several generations of flank ridges, having different heights and sizes, are identifiable. The old ridges contrast significantly with the size of the presently forming flank ridges associated with the active earth flow. Typically the largest ridge is in the outermost position. The outermost ridge presumably was formed at the time of the initial failure of the landslide. Toward the inner part of the landslide, smaller ridges record separate and successive changes in the landslide boundary. 
Smaller ridges that formed inside the older and larger ridges could result from the continual downslope movement of a gradually decreasing volume of material. In a few places, smaller lateral ridges are present on the outside of very large ones bounding the earth flow. Small ridges can be observed parallel to but outside larger ridges, for example, where State Highway 149 crosses the landslide.

Secondary slope movements, mostly rotational slides, falls and flows, were observed on the sides of several flank ridges at the Slumgullion landslide. Slope movements are present, for example, on the main left flank ridge downslope from the active toe; downcutting by Slumgullion Creek on one side, and by a perennial stream on the other causes frequent slope movements (Parise and Moscariello, 1997).

The several generations of flank ridges present on both the sides of the inactive Slumgullion earth flow were mapped on aerial photographs and later field checked. We also surveyed the characteristics of several lateral ridges to understand the chronology of their formation and the variability of their features. These included the size of the ridges (both in absolute terms and relative to other landslide materials), their reciprocal relationships, main direction of their axes, and the presence and type of vegetation cover and of soils (the latter being described also by means of the Munsellis color charts, Munsell, 1954).

Two areas were selected for detailed description of the flank ridges on the Slumgullion landslide: the first is located at the middle-upper portion of the slide, near its narrowest part, and the second area is immediately downhill from the active toe.

These areas were chosen because they show a well-preserved sequence of flank ridges on both sides of the earth flow. Moreover, they show interesting aspects of kinematics and deformation of the landslide deposits. In fact, the narrowest part of the landslide has the highest average rate of movement at the Slumgullion earth flow, that is about $6.0 \mathrm{~m} /$ year (Crandell and Varnes, 1961; Guzzi and Parise, 1992; Savage and Fleming, 1996; Fleming and others, 1996).

\section{Flank Ridges Near the Narrowest Part of the Landslide}

Several generations of flank ridges bound the middle-upper part of the active earth flow. This area is adjacent to the most narrow and fastest moving part of the active Slumgullion landslide and has local flank ridges forming in the actively moving part. On the north side is an area termed secondary source area that was evidently a source of landslide debris that predates all but the earliest flank ridges. On the basis of geomorphological (height and width of the ridge, shape, slope gradient on inner and outer slopes) and sedimentological (soil type, sedimentology of deposits) features, and of the development of soils and vegetation on the ridges, a chronology of the formation of flank ridges can be demonstrated.

The reconstruction (fig. 3) of ages for ridges is numbered from (1) to (4), with (1) being the oldest. Number (1) refers to a phase probably related to the movement of material from the secondary source area, due to its orientation, diverging from most of those of the other ridges. It is fairly well vegetated with aspens and spruce/fir, and its slopes are quite smooth, due to the effect by the erosional processes, after its formation. This ridge was cut by the development of the flank ridge labeled as (2) whose main axis follows the direction of the active earth flow. This ridge also steps to the left a few tens of meters uphill. The innermost ridge, i.e. the one closest to the present active earth flow boundary (labeled as (3), has good continuity and $a$ fresher appearance than the two previous sets. These young ridges have higher values of slope gradient and, at several sites (marked by asterisks in fig. 3), the inner slopes of the ridges are affected by minor slope movements.

At the upper sector of the area shown in figure 3 , another set of flank ridges (labeled as (4)), is present. This set is the youngest of the inactive lateral ridges, and shows smaller values for its morphometric parameters (cf. table 2).

The generations of flank ridges on the right side of the earth flow were also partially identified and correlated with those on the left side. Ridges belonging to set (1) could not 
TABLE 2.--Features used for the chronology of formation of the flank ridges at the narrowest part of the Slumgullion earth flow. Sets of flank ridges labeled as in figs. 3 and 4 , and as in the text.

\begin{tabular}{|c|c|c|c|c|c|}
\hline $\begin{array}{l}\text { Set of } \\
\text { flank } \\
\text { ridges }\end{array}$ & $\begin{array}{l}\text { Maximum } \\
\text { height } \\
\text { (h) }\end{array}$ & $\begin{array}{c}\text { Maximum } \\
\text { width } \\
\text { (w) }\end{array}$ & $\begin{array}{c}\text { Inner } \\
\text { slope } \\
\text { gradient } \\
\end{array}$ & $\begin{array}{l}\text { Vegetation } \\
\text { cover }\end{array}$ & $\begin{array}{c}\text { Munsell's } \\
\text { soil } \\
\text { color } \\
\end{array}$ \\
\hline (1) & $10 \mathrm{~m}$ & $24 \mathrm{~m}$ & $30^{\circ}$ & $\begin{array}{c}\text { fully } \\
\text { vegetated }\end{array}$ & $\begin{array}{c}\text { very pale brown } \\
\text { [10YR 7/4] }\end{array}$ \\
\hline (2) & $14 \mathrm{~m}$ & $32 \mathrm{~m}$ & $36^{\circ}$ & $\begin{array}{c}\text { fully } \\
\text { vegetated }\end{array}$ & $\begin{array}{c}\text { brownish yellow } \\
\text { [10YR 6/6] }\end{array}$ \\
\hline (3) & $18 \mathrm{~m}$ & $48 \mathrm{~m}$ & $40^{\circ}$ & partly vegetated & $\begin{array}{c}\text { yellow [10YR 7/6] } \\
\text { with pinkish gray patches } \\
{[7.5 \mathrm{YR} 6 / 2]}\end{array}$ \\
\hline (4) & $8 \mathrm{~m}$ & $20 \mathrm{~m}$ & $35^{\circ}$ & $\begin{array}{l}\text { partly vegetated; } \\
\text { locally no } \\
\text { vegetation }\end{array}$ & $\begin{array}{c}\text { yellowish red } \\
{[5 Y R \text { 5/8] }}\end{array}$ \\
\hline $\begin{array}{l}\text { dashed } \\
\text { ridge }\end{array}$ & $5 \mathrm{~m}$ & $33 \mathrm{~m}$ & $16^{\circ}$ & $\begin{array}{c}\text { fully } \\
\text { vegetated }\end{array}$ & $\begin{array}{c}\text { yellow [10YR 7/8] - } \\
\text { brownish yellow } \\
{[10 Y R 6 / 8]}\end{array}$ \\
\hline
\end{tabular}

TABLE 3.- - Estimated values of width and thickness of the Slumgullion landslide, after the formation of main sets of flank ridges recognized on the landslide.

\begin{tabular}{|c|c|c|c|c|c|c|}
\hline & \multicolumn{2}{|c|}{$\begin{array}{c}\text { Time of formation } \\
\text { of set (2) }\end{array}$} & \multicolumn{2}{|c|}{$\begin{array}{c}\text { Time of formation } \\
\text { of set (3) }\end{array}$} & \multicolumn{2}{|c|}{ Present time } \\
\hline & width & thickness & width & thickness & width & thickness \\
\hline Narrowest part of the slide & $267 \mathrm{~m}$ & $47 \mathrm{~m}$ & $204 \mathrm{~m}$ & $37 \mathrm{~m}$ & $170 \mathrm{~m}$ & $30 \mathrm{~m}$ \\
\hline Downslope from active toe & $510 \mathrm{~m}$ & $119 \mathrm{~m}$ & $444 \mathrm{~m}$ & $126 \mathrm{~m}$ & $300 \mathrm{~m}$ & $114 \mathrm{~m}$ \\
\hline
\end{tabular}


be identified on the left side, and ridge (3), at the left lower corner of figure 3 , bifurcates into two parts. The dashed ridge in intermediate position between those labeled (2) and (3) is not very well defined morphologically, and we were not able to fit it in the chronology reconstruction. Development of vegetation and soil are, however, similar as for (2), but its height is smaller (table 2).

Variations in size of the flank ridges can be used to estimate previous width and thickness of the landslide at the time of formation of the flank ridges. Comparison of such estimates with presently observed values of width and thickness provides clues about the landslide evolution (Fleming and others, 1988).

At the Slumgullion earth flow, flank ridge sets (2) and (3) were used in this analysis because of their continuity along most of the landslide.

Data in table 3 show that at the narrowest part of the Slumgullion earth flow the diminishing width of the landslide occurred with a reduction in the thickness of material involved in movement. The diminution in thickness seems to be of particular interest. Since the time of formation of the flank ridge set (2) the maximum height of the landslide diminished $36 \%$. Likewise, the present width of the active landslide appears to have been reduced by perhaps $50 \%$.

\section{Flank Ridges Downslope From the Active Toe}

We also studied flank ridges at the middle part of the inactive Slumgullion landslide, just downhill from the active toe (fig. 5). There, flank ridges are well-preserved on both sides of the landslide, and form the most conspicuous feature here. Geomorphic and sedimentologic characters of the flank ridges were again investigated, but only a very simple chronology of their formation could be developed.

Most of the observed features of flank ridges in this sector are similar, and ridges were correlated largely on the basis of position. However, some differences occur between flank ridges on the right and left side of the inactive landslide. The right flank ridge is very long and narrow, with a sharp crest and slopes up to $35^{\circ}$ (fig. 6). It is proba- bly the analog of set (3) adjacent to the active landslide. The ridge is formed from two long segments, truncated near the active toe of the landslide (elevation about $3,000 \mathrm{~m}$; fig. 5) by material coming from a unnamed right tributary of the old Slumgullion Creek. The area between the two segments is presently occupied by a marshy beaver pond. The main right flank ridge, that is set (3), shows on its outer position remnants of another set of flank ridges, cut by the State Highway 149. The latter are smaller with respect to the inner ridge and are very flat, with gentle slopes and a general rounded shape (fig. 6); soil and vegetation characteristics are the same as those of set (3). Therefore, we interpreted these ridges as depositional ridges formed as a result of overflowing of landslide material coincidently with the main flank ridge (deformational type); these ridges are labeled as set (3a in figures 5 and 6 .

No depositional ridges were found on the left side of the inactive landslide downslope from the active toe. A $90 \mathrm{~m}$ wide and $25 \mathrm{~m}$ high flank ridge (belonging to set (3) bounds the earth-flow deposit on this side. The ridge is bounded on both sides, by Slumgullion Creek on the south, and by a perennial stream flowing from the active toe on the north. The streams cause downcutting of side slopes of the ridge and promote local slumps and falls. The top of the main left ridge is flat in its wider part, and does not show a well-defined axis; at sites, a double crest can be recognized (see for example profile D-D1 in fig. 6). A 150-m-long flank ridge belonging to set (2) is present at the outer side of the main left ridge (fig. 5).

The narrowing of the landslide from more than $500 \mathrm{~m}$ at the time of formation of sets (2), to the present width of $300 \mathrm{~m}$ was not accompanied by a significant decrease in thickness (table 3). The thickness remained about constant around average values of 115-120 m (Parise and Guzzi, 1992).

The narrowing from 500 to $300 \mathrm{~m}$ represents about a $40 \%$ decrease in volume. The $40 \%$ reduction in volume was sufficient to allow movement to stop in the region downhill from State Highway 149. The reduction in volume at the narrowest part of the landslide is much larger, but active movement continues in that region. 


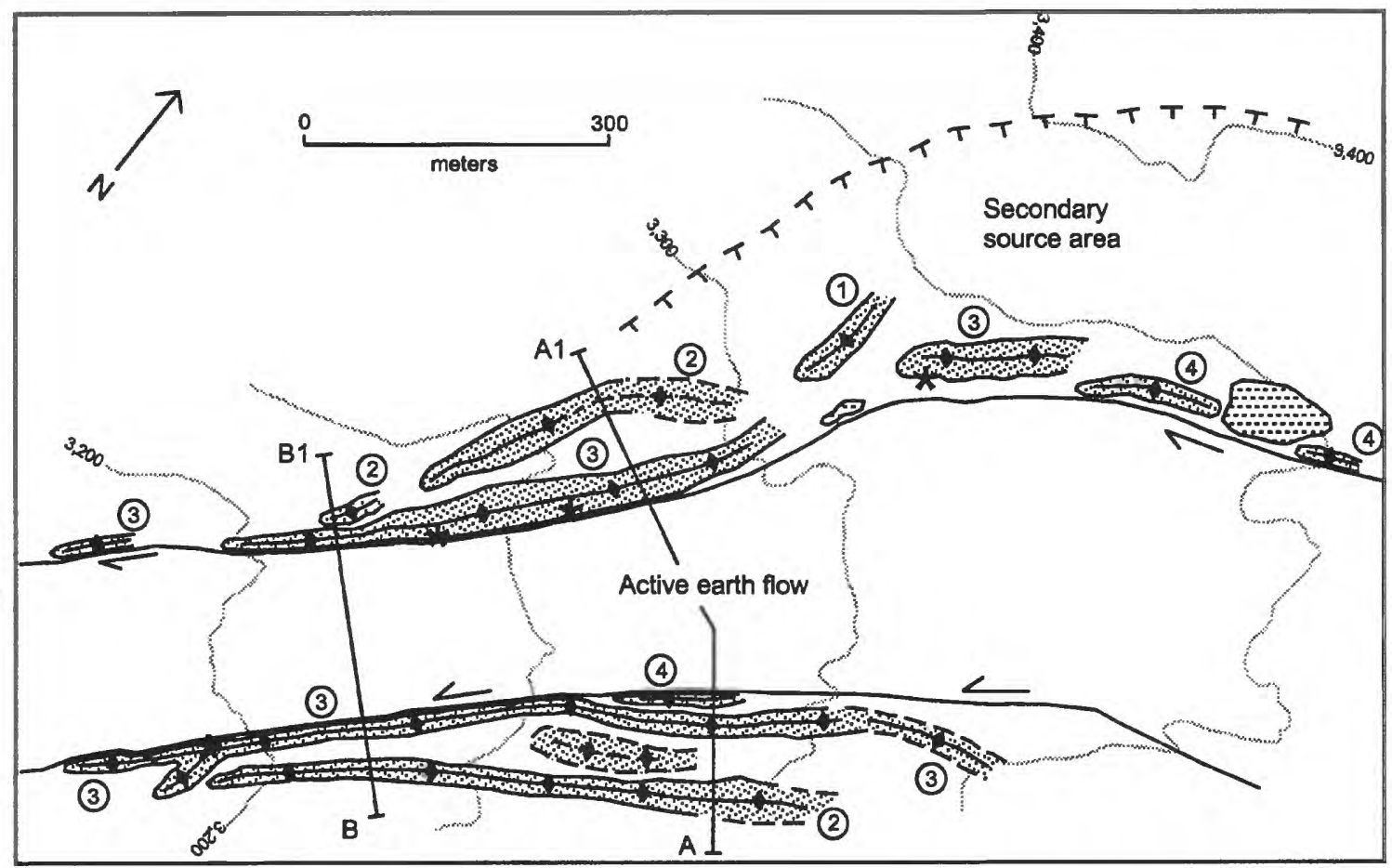

FIGURE 3. Sketch of the sector near the secondary source area on the right side of the earth flow, showing the several generations of inactive lateral ridges and their relative chronology (from the oldest (1) to the youngest (4). Location is at the most narrow part of the active earth flow. See text for explanation. Traces of the transverse profile of fig. 4 are shown.

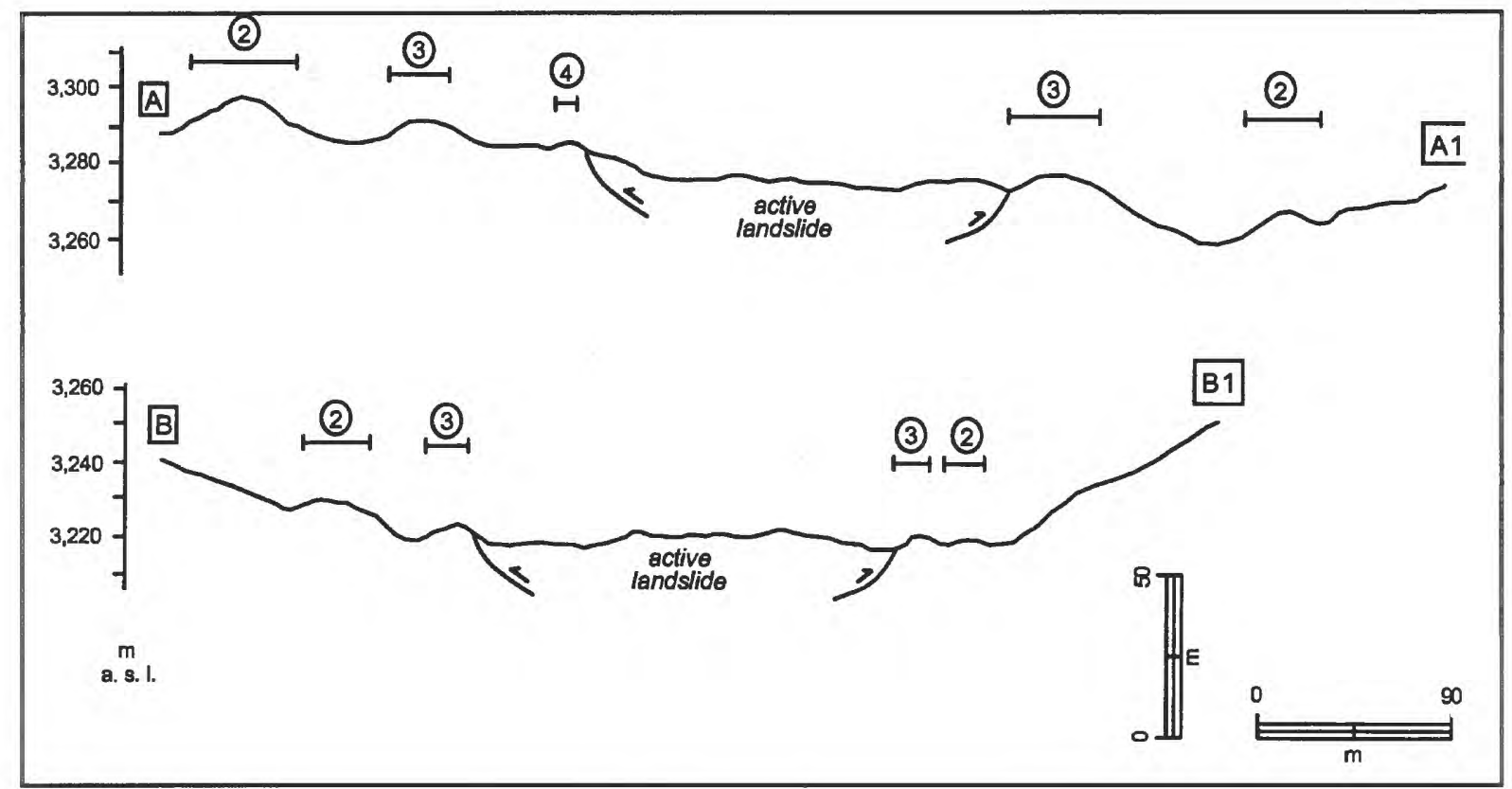

FIGURE 4. Transverse profiles (looking downslope) at the narrowest part of the earth flow. Location of profiles are shown in fig. 3. 


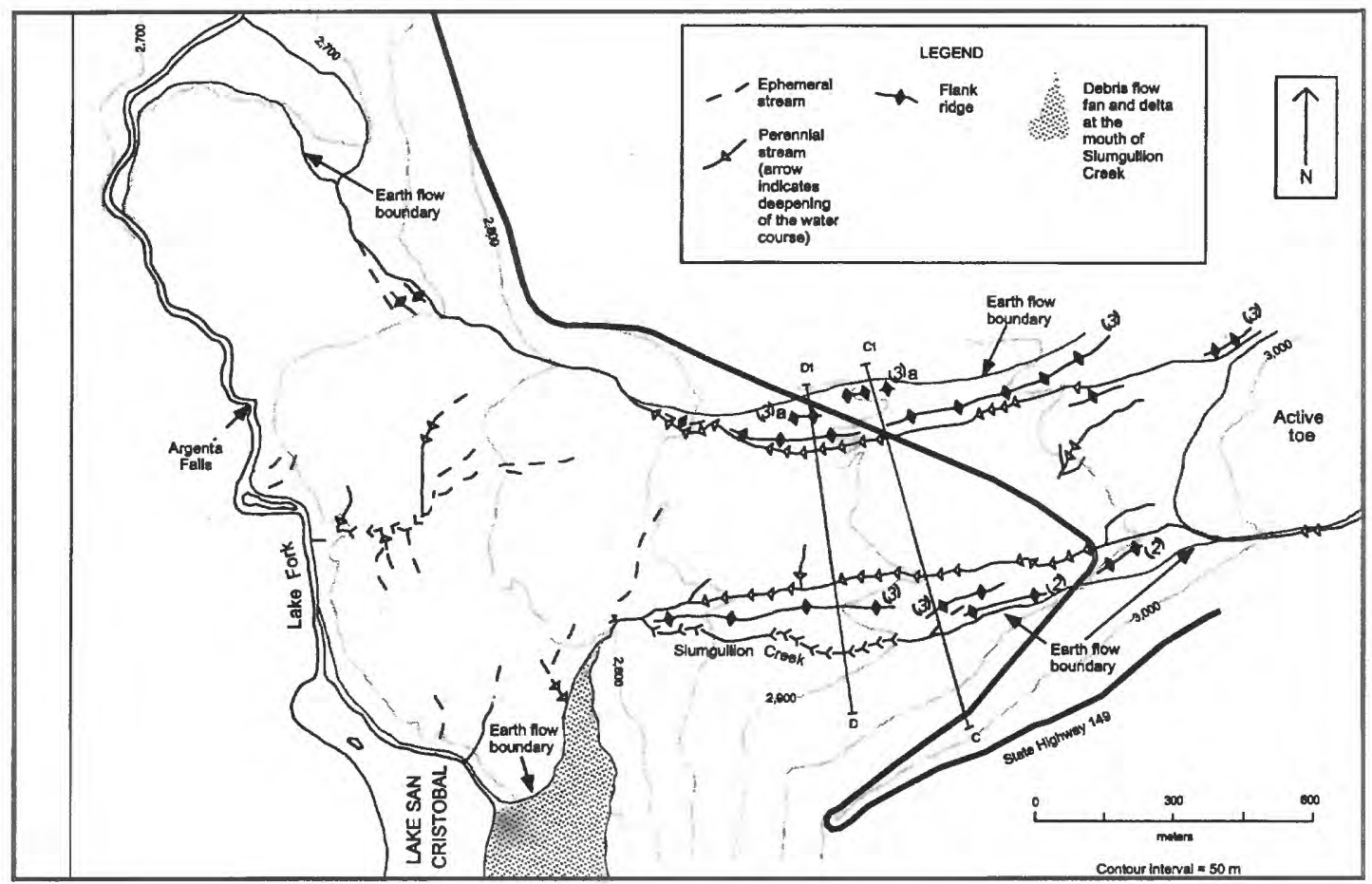

FIGURE 5. Simplified geomorphological sketch of the middle-lower portion of the Slumgullion earth flow, from the active to the inactive toe. Traces of the transverse profiles of fig. 6 are shown.

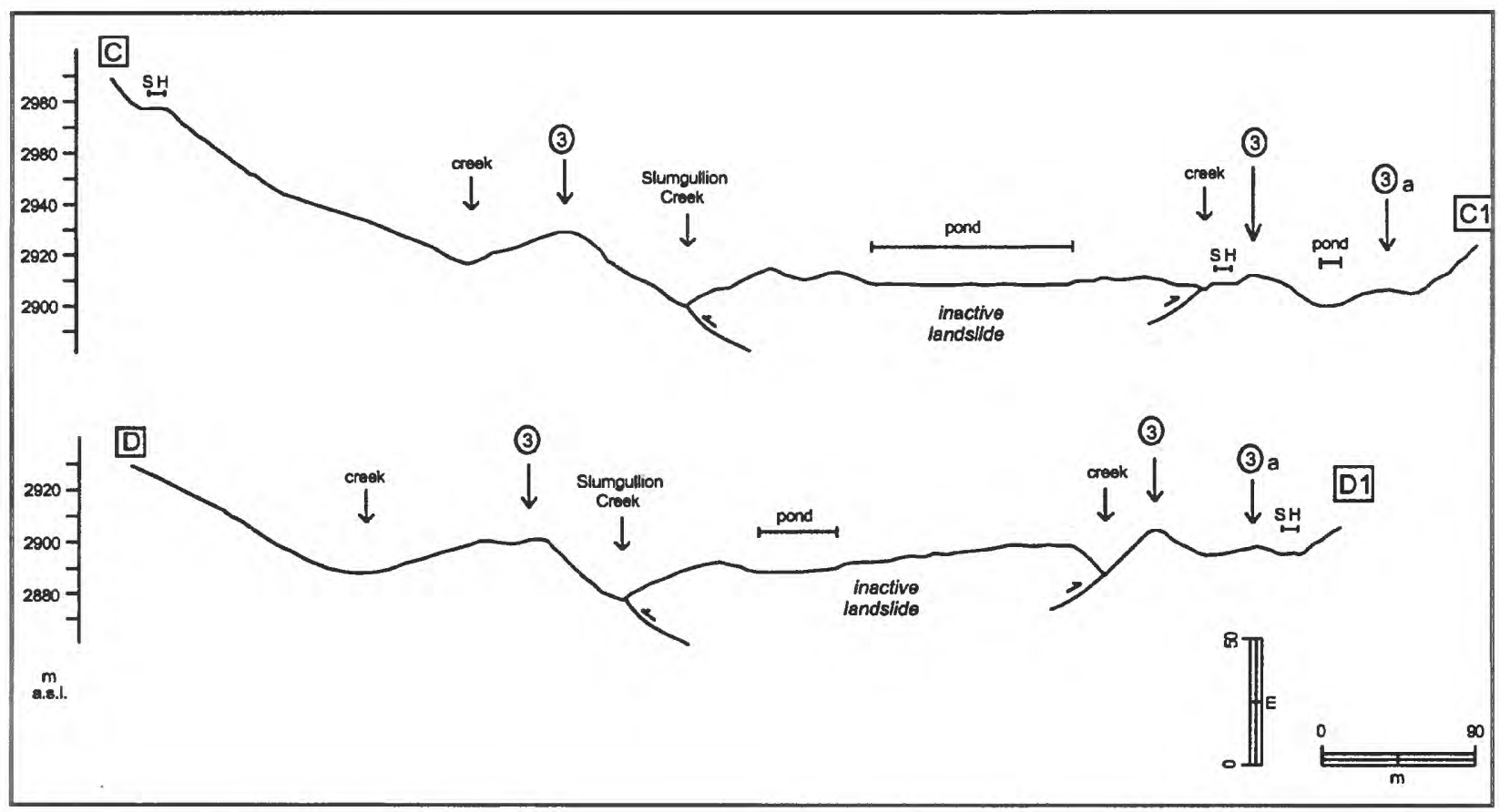

FIGURE 6. Transverse profiles (looking downslope) at the middle-lower part of the old Slumgullion earth flow. Location of profiles are shown in fig. 5. SH is State Highway 149. 


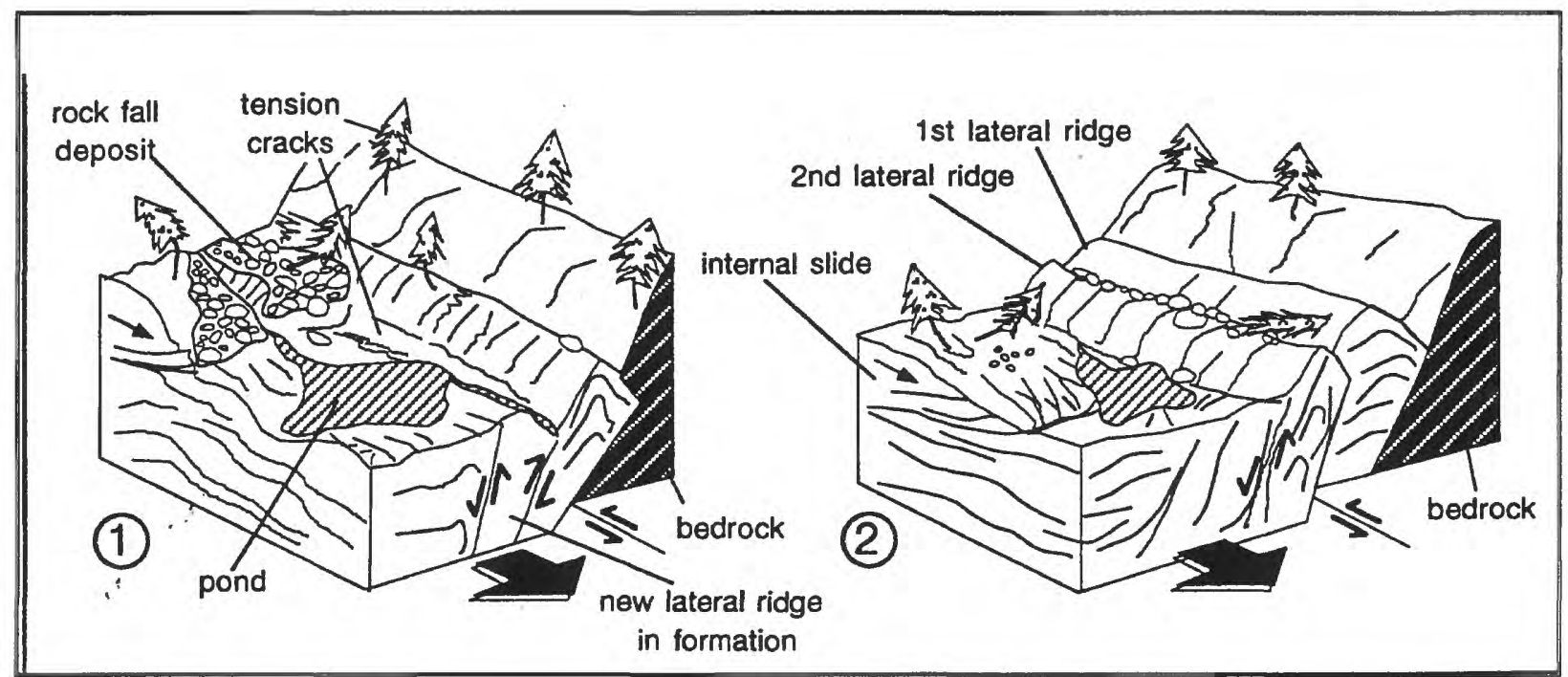

FIGURE 7. Block diagram showing a possible model explaining the concentration of large boulders at the top of lateral ridges at the Slumgullion earth flow.

\section{DISCUSSION AND CONCLUSIONS}

Insofar as we know, this is the first attempt to relate flank ridges adjacent to a landslide to its history of movement. It appears that the oldest flank ridges can be associated with the episode of movement that blocked Lake Fork and created Lake San Cristobal. The landslide exhibits a consistent pattern of narrowing and, in the upper part, of thinning that will ultimately lead to a cessation of movement.

As a result of this study, it appears that detailed mapping of the ridges combined with documentation of the materials and presence or absence of pedologic soils could provide valuable information on the history of movement and help to ascertain whether movement has been episodic or continuous over the past 1200 years (see also Madole, 1996). The correlation of ridges at the two localities we studied was based on morphology and position with respect to the inactive landslide boundaries. Whether such correlations can be demonstrated to be accurate can only come from tracing their extent in the field and projecting their traces across intervals where ridges have been obliterated by more recent movement.
An intriguing issue on the origin of lateral ridges is the presence of large boulders aligned along their crest. The boulders are generally arranged with their longest axis at right angles with respect to the trend of the ridge. Field observations at the contact between the rock-fall deposits at the upper portion of the Slumgullion landslide (Parise and Moscariello, 1997) and the active leftlateral ridge suggest that the large boulders present on top of narrow ridges could be interpreted as the remnants of a wider cover made up by large blocks that was reworked and dismembered by the building up of the flank ridges (fig. 7). Large boulders are in fact found at the ridge side slopes that have slid or rolled down from the ridge crest during its formation. Large boulder fields, probably related to ancient rock-fall events, are recognizable only at the main scarp foothills and at the upper Slumgullion earth flow; moving downslope, namely from where the bounding shear surface reaches the ground, the boulders do not form such features, but they are mostly dispersed and scattered along the body of the earth flow.

In a way similar to the one just described, other authors have interpreted in different types of flow-like gravitational movements the presence of boulders and coarse material 
on top of the lateral ridges as related to erosion following the phase of deposition. For example, Curry (1966) has inferred that ridges of boulders were the result of washing of the fine materials out of old mudflow deposits; his conclusion was also supported by observations of a mudflow at Steele Creek, Yukon (Broscoe and Thomson, 1969).

The recognition of several generations of flank ridges on the sides of the Slumgullion landslide is consistent with the history of movement of the landslide. Fleming and others (in press) described at least four episodes of movement of the landslide: the first episode blocked Slumgullion Creek, about 1000-1300 years ago; the second episode blocked Lake Fork and caused the impoundment of Lake San Cristobal, about 800-900 years ago; the third episode was collapse of the north part of the headscarp, about 300 years ago; the fourth episode is the reactivation of old landslide deposits, and is represented by the current episode of movement (Fleming and others, in press).

We lack absolute dating for the identified sets of flank ridges, so no absolute correlation between the four episodes of movement summarized above and the flank ridges can be made. However, it is reasonable to assume that the most developed of the outer sets of flank ridges, the flank ridge labeled as (2) in this report, was related to the first episode of movement of the landslide. Set (3, the most continuous along the landslide, was formed during the second phase of movement, when the large majority of material moved down the valley of Slumgullion Creek. Set (4) is probably related to minor episodes of movement within the body of the landslide. Finally, presently forming flank ridges, not described in detail in this report, are recognizable along the shear surfaces bounding the active Slumgullion earth flow; they are related to the current phase of movement.

Analysis of flank ridges at the Slumgullion landslide indicated past boundaries and height of the landslide; distribution of the ridges shows evidence for gradual thinning and narrowing of the earth flow. Thinning and narrowing, due to decreasing sediment discharge from the source area, progressed until the lower reaches of the landslide could no longer move. Similar thinning and narrowing documented by recent mapping (Fleming and others, in press) will eventually result in inactivity of the presently active part of the landslide unless there is an increase of material available in the source area.

\section{ACKNOWLEDGMENTS}

This research is part of the post-doctoral activity of A. Moscariello granted by the Swiss National Science Foundation. This research has also been partly sponsored by the Académie Suisse de Sciences Naturelles and Fond Édouard Claparède, Geneva.

David J. Varnes supplied useful data and information. Comments by Rex L. Baum on a first draft of the paper and by William $Z$. Savage greatly improved the final version. We thank these people for their help and assistance.

\section{REFERENCES}

Baum, R.L. and Fleming, R.W., 1996, Kinematic studies of the Slumgullion landslide, Hinsdale County, Colorado, in Varnes, D.J. and Savage, W.Z.. eds., The Slumgullion earth flow-a large-scale natural laboratory: U.S. Geological Survey Bulletin 2130, p. 9-12.

Baum, R.L., Fleming, R.W. and Johnson, A.M., 1993, Kinematics of the Aspen Grove landslide, Ephraim Canyon, central Utah, in Landslide processes in UtahObservation and theory: U.S. Geological Survey Bulletin 1842, p. F1-F34.

Blackwelder, E., 1928, Mudflow as a geologic agent in semiarid mountains: Geological Society of America Bulletin, 39, p. 465484.

Broscoe, A.J. and Thomson, S., 1969, Observations on an alpine mudflow, Steele Creek, Yukon: Canadian Journal of Earth Sciences, 6, p. 219-229.

Chleborad, A.F., 1993, Description, origin, and implications of a new identified Slumgullion landslide deposit, San Juan Mountains, southwestern Colorado: U.S. Geological Survey Open-File Report 93548,17 p. 
Corominas, J., 1995, Evidence of basal erosion and shearing as mechanism contributing to the development of lateral ridges in mudslides, flow-slides, and other flow-like gravitational movements:

Engineering Geology, v. 39, p. 45-70.

Crandell, D.R. and Varnes, D.J., 1961, Movement of the Slumgullion earth flow near Lake City, Colorado, in Short Papers in the Geologic and Hydrologic Sciences: U.S. Geological Survey Professional Paper 424-B, p. B136-B139.

Cross, W., 1909, The Slumgullion mud flow: Science, v. 30, no. 760 , p. 126-127.

Curry, R.R., 1966, Observations of alpine mudflows in the Tenmile Range, central Colorado: Geological Society of America Bulletin, v. 77, p. 771-776.

Fleming, R.W. and Johnson, A.M., 1989, Structures associated with strike-slip faults that bound landslide elements: Engineering Geology, v. 27, p. 39-114.

Fleming, R.W., Johnson, R.B. and Schuster, R.L., 1988, The reactivation of the Manti landslide, Chapter A of The Manti landslide, Utah: U.S. Geological Survey Professional Paper 1311, p. 1-22.

Fleming, R.W., Baum, R.L. and Savage, W.Z., 1996, The Slumgullion landslide, Hinsdale County, Colorado, in Guidebook for field trips: Geological Society of America Annual Meeting, Denver, Colo., October 1996 (Available on CD-Rom from the Colorado Geological Survey), 21 p.

Fleming, R.W., Baum, R.L. and Giardino, M., in press, Map and description of the active part of the Slumgullion landslide, Hinsdale County, Colorado: U.S. Geological Survey Miscellaneous Field Studies Map, scale 1:1,000, 3 sheets with pamphlet.

Guzzi, R. and Parise, M., 1992, Surface features and kinematics of the Slumgullion landslide, near Lake City, Colorado: U.S. Geological Survey Open-File Report 92252, 45 p.
Hadley, J.B., 1964, Landslides and related phenomena accompanying the Hebgen Lake earthquake of August 17, 1959: U.S. Geological Survey Professional Paper 435K, p. 107-138.

Howe, E., 1909, Landslides in the San Juan Mountains, Colorado: U.S. Geological Survey Professional Paper 67, 58 p.

Johnson, A.M., 1970, Physical processes in geology: San Francisco, Calif., Freeman, Cooper and Co., 577 p.

Keefer, D.K. and Johnson, A.M., 1983, Earth flows: morphology, mobilization, and movement: U.S. Geological Survey Professional Paper 1264, 56 p.

Madole, R.F., 1996, Preliminary chronology of the Slumgullion landslide, Hinsdale County, Colorado, in Varnes, D.J. and Savage, W.Z., eds., The Slumgullion earth flow-a large-scale natural laboratory. U.S. Geological Survey Bulletin 2130, p. 5-7.

Munsell, 1954, Munsell soil color charts: Munsell Color Company Inc., Baltimore, Maryland, USA.

Parise, M. and Guzzi, R., 1992, Volume and shape of the active and inactive parts of the Slumgullion landslide, Hinsdale County, Colorado: U.S. Geological Survey Open-File Report 92-216, 29 p.

Parise, M. and Moscariello, A., 1997, Geologic hazards and relative slope stability of the inactive part of the Slumgullion landslide, southwestern Colorado: U.S. Geological Survey Open-File Report 97706, 16 p.

Rickmers, W.R., 1913, The Duab of Turkestan-a physiographic sketch and account of some travels: London, Cambridge University Press, 197 p.

Savage, W.Z. and Fleming, R.W., 1996, Slumgullion landslide fault creep studies, in Varnes, D.J. and Savage, W.Z., eds., The Slumgullion earth flow-a large-scale natural laboratory: U.S. Geological Survey Bulletin 2130, p. 73-76. 
Sharp, R.P., 1942, Mudflow levees: Journal of Geomorphology, 5, p. 222-227.

Varnes, D.J., Smith, W.K., Savage, W.Z. and Powers, P.S., 1996, Deformation and control surveys, Slumgullion landslide, in Varnes, D.J. and Savage, W.Z., eds., The Slumgullion earth flow-a large-scale natural laboratory: U.S. Geological Survey Bulletin 2130, p. 43-49.

WP/WLI (Working Party on World Landslide Inventory), 1993, A suggested method for describing the activity of a landslide: Bulletin of the International Association of Engineering Geology, 47, p. 53-57. 